\title{
TÜKETIM KÜLTÜRÜ VE
}

\section{TÜKETIM KÜLTÜRÜ EKSENINDE YOKSUL SANAT ANLATISI}

\author{
Süleyman İRGIN ${ }^{1}$
}

ÖZ

Tüketim, mal ve hizmetlerin bireylerin ihtiyaçlarını karşılayacak şekilde kullanılmasıdır. $\mathrm{Bu}$ şekilde ihtiyaçların karşılanması birey ve bireylere fayda sağlamaktadır. Tüketim, pratik bağlamda nihai bir kullanım demektir. Yani mal ve hizmetlerin daha da ileri bir işleme tabi tutmak veya yeniden dolaşıma sokmak üzere insanların ihtiyaçlarını karşılayacak düzeyde satın alma işlemidir diyebiliriz. Atık nesnelerin henüz icat edilmediği eski çağlardan-dönemlerden gelen insanlar, nesneleri atmayıp biriktiriyorlardı ya da başka bir nesnenin formuna-işlevselliğine dönüştürüyorlardı. Tüketim toplumlarında nesneler satın alınır-alınmaz hemen atığa dönüşmektedir. Kapital(ist) bir toplumda atığa çıkartılan nesneleri yeniden dolaşıma sokmak ve bir sanat nesnesinin malzemesi yapmak, mevcut sisteme bir muhalefet ve avangard (öncü, yenilikçi) bir tutum olarak durabilir. Bu bağlamda Arte Povera (yoksul sanat)'nın geçmişine baktığımızda, öncelikle ortaya çıkışındaki sosyo-kültürel ve ekonomik unsurların ideolojik kurgulamalarla ne denli zorlayıcı faktörler yaratmış olduğunu ve temelde "insan" olgusunun bu unsurlar altında giderek daha da güçsüz hale geldiğini ifade etmek gerekir. Tüm bu referanslarla birlikte, sanatın öz'e yani saf olana geri dönüşü, sanatçıların farkındalık kazandırma ve eleştirel bir tavır takınma süreçleri Arte Povera'nın ruhunu oluşturmaktadır.

Anahtar Kelimeler: Sanat, Tüketim, Arte Povera, Atık Nesne

${ }^{1}$ Dr. Aksaray Üniversitesi Eğitim Fakültesi Güzel Sanatlar Eğitimi Bölümü / 68200 Aksaray suleymanirgin(at)gmail.com 


\title{
CONSUMPTION CULTURE AND POOR ART EXPRESSION IN THE AXIS OF CONSUMPTION CULTURE
}

\begin{abstract}
Consumption is the use of goods and services to meet the needs of individuals. Meeting the needs in this way is beneficial to individuals and individuals. Consumption is the ultimate use in a practical context. In other words, we can say that it is a level of procurement that meets the needs of people to carry out further processing or recirculation of goods and services. People from ancient times-where waste objects were not yet invented-were not throwing away objects or converting them into formfunctioning of another object. In consumer societies, objects are purchased - they are transformed immediately into a market. In a capitalist society, re-circulating objects and making the material of an art object stand as an opposition and avant-garde attitude to the existing system. In this context, when we look at the past of Arte Povera (poor art), we must first state that the socio-cultural and economic elements of its emergence have created compelling factors with ideological constructions, and basically the "person" becomes increasingly weak under these elements. Along with all these references, Arte Povera's spirit is the process of returning the essence of art to the pure, raising the awareness of the artists and taking a critical attitude.
\end{abstract}

Key Words: Art, Consumption, Arte Povera, Consumption Object

İrgin, Süleyman, "Tüketim Kültürü ve Tüketim Kültürü Ekseninde Yoksul Sanat Anlatisi". idil 5.27 (2016): 1923-1936.

Irgin, S. (2016). Tüketim Kültürü ve Tüketim Kültürü Ekseninde Yoksul Sanat Anlatıs1.idil, 5 (27), s.1923-1936. 
Günümüzde tüketimin kültür kavramıyla yan yana gelmesi, tüketim alışkanlığının farklı boyutlara ulaşmasından kaynaklanmaktadır. Aslında tüketim, kullanılması zorunlu olan tüketim nesnelerinin tüketilmesini ifade ederken, 19. yüzyıldan sonra ortaya çıkan sanayileşmenin topluma sunduğu birçok üretim nesnesinin tüketilme zorunluluğu varmışçasına topluma dayatılmasından kaynaklanmaktadır. Tüketim kültürü Featherstone'a göre; değişen göstergeler, imajlar ve simgeler ağıyla bütünleşmiştir. Featherstone, bu bütünleşme içindeki tüketim kültürünü üç perspektifte ele almıştır. Bunlardan ilki, kapitalist meta üretiminin genişlemesi, ikincisi toplumsal statü edinme isteği, üçüncüsü ise tüketicinin bilinçaltına hitap edilerek hazlar, rüyalar ve arzular yaratılmasının ortaya koyduğu psikolojik sorunlardır. Tüketim sisteminin bütün kategorileri birbirine bulaşabilir kıldığını söylemekte ve türlerin karışmasını "kültürün fotokopileşmesi" olarak yorumlamaktadır. Her tür etkinlik kültür olarak adlandırılmaktadır. Reklamlardaki göstergeler bir bakıma kültürleri fotokopileştirmektedir. Steven Connor'a göre, postmodernist kültür söz konusu olduğunda, kültürü diğer şeylerden ayırt etmek imkânsızlaşmaktadır.

Tüketim kapitalizmine karşı durulmaya çalışıldığında, kültürden destek almanın yolu kalmamıştır. Postmodern dönemde, farklılaşma tamamen çökmekte gibidir. Farklı kültürlere aitmiş gibi görünen imgeler, gerçekten kültürlerin belirleyici özelliklerine sahip olmak yerine, yeni toplumsal yapılar, yeni kültürler oluşturacak politikalara hizmet etmektedir. Bu durumu Yaşar şu şekilde ifade eder: "Tüketim toplumunun tüketimi için arz edilen sanayi ürünlerinin büyük bir bölümünü, kullanıp atılmaya uygun olanları oluşturmaktadır. Bu durum insan varlığının beğenisinin tüketilebilen bir nitelik kazanmasını sağlamıştır. Yani, tüketimin kendisi zevk haline dönüşmüştür" (Yaşar, 2006: 115).

$\mathrm{Bu}$ açıdan değerlendirecek olursak, üretim ve tüketim arasında bir arz-talep ilişkisinden söz edebiliriz. Toplumun ihtiyacı olan tüketim nesnelerinin yanında ihtiyacı olmadığı halde seri üretim mantığıyla üretilen ürünlerin olduğu bir dünyada “üretim kültürü” kavramından söz etmek yerinde olacaktır. Üretim kültürünün olduğu bir yerde "tüketim kültürü”nden söz etmemiz kaçınılmazdır. Dolayısıyla "üretim kültürü” ve “tüketim kültürü’nün olduğu bir yerde Yaşar'ın da ifade ettiği gibi "tüketim toplumu"ndan da bahsetmemiz gerekmektedir. Tüketim toplumu tabiri, batıda sanayileşme sonrası ortaya çıkan toplum şeklini tarif etmek için de kullanılmaktadır. Seri üretimin artmasıyla hızla değişen arz-talep dengesi, üreticileri ve hükümetleri farklı siyasi-politik düşüncelere itmiş üretilenlerin hızlı tüketilmesini sağlamak amacıyla çeşitli yollar denenmiştir ve uygulanmıştır. 
$\mathrm{Bu}$ yolların en önemli vasıtalarından biri de hiç şüphesiz ki bilişim ve iletişim vasıtalarıdır. Yazılı ve görüntülü basınla birlikte son yıllarda bunu geçeceği ön görülen internet, tüketim toplumunu yönlendirmede ve manipüle etmede kullanılan başlıca kaynaklardır.

Artık ihtiyaçlar medya tarafından belirlenmekte, neyin ihtiyaç olduğunu düşünecek zamanı bulamayan tüketici, önüne sunulan alternatiflere "evet-hayır" yanıtından birini verebilecek kadar bir zamanı ancak bularak buna bir şekilde yanıtlar üretmektedir. Tüketim toplumunun meydana gelişinin altında yatan sebepleri ortaya koyarken şunları da ifade etmektedir: Tarihte olayların iki defa vuku bulduğu olur. Birincisinde bu olaylar-olgular gerçek tarihi bir değere sahipken, ikincisi birincisinin karikatürüdür ve grotesk (garip, acayip...) bir serüvendir ve efsane olmuş bir atıftan beslenir. $\mathrm{Bu}$ tespit ve tespitlerin ardından Baudrillard, yitirdiğimiz değerleri ve gerçekliğin yerini tutamayan suni (yapay-inorganik) düzenlemlerle telafi etmeye çalıştığımızı belirtmektedir. "Baudrilların ifadelelerinden yola çıkan Featherstone'a göre toplumsal hayat kurallardan arındırıldıkça ve toplumsal ilişkiler değişkenleşip istikrarlı normlarca daha az yapılanmış hale geldikçe tüketim toplumu özünde kültürel bir toplum haline gelir. Göstergelerin aşırı üretimi ve imajlarla simülasyon (benzetim)'ların yeniden üretimi, istikrarlı anlamın yitişine ve izleyiciyi istikrar duygusunun ötesine taşıyan çarpıcı kolâjların sonsuz akışından kitlelerin büyülenmesiyle gerçekliğin estetikleştirilmesine yol açar” (Featherstone, 2013: 42). "Televizyonun ve sinemanın, görüntünün, görselleşmenin ve de kitle reklamcılığının sunduğu tarzların egemenliğindedir” (Hall, 2014: 47,48).

"Tüketim toplumu bir başka ifadeyle tüketim olgusunun topluma öğretilmesi/alıştırılmasıdır. Tüketim olgusuna alıştırılan toplum farkında olmadan yeni üretici grupların sisteme dâhil olmasına neden olur. $\mathrm{Bu}$ sayede üretilen malların tekelci bir anlayışla yeniden yapılandırılması süreci karşımıza çıkar. Bir bakıma yeni bir toplum tipinin yaratılmasında rol oynar" (Baudrillard, 2013: 87). "Kapitalist sistemin hüküm sürdüğü bu dönemde estetik anlayışının, özgünlük ve o özgünlük dışında kalanların yadsımasına dayandığı söylenebilmektedir. Sanatçı, artık ürünlerini pazara çıkarmakta ve sanatını yeniden üretebilmek için diğer sanatçılar ile pazarda yarışmak durumunda kalmaktadır” (Şaylan, 2009: 107).

$\mathrm{Bu}$ dönemde estetik kavramında, endüstri devri öncesi ve sonrası olarak değişimler göze çarpmaktadır. Endüstri toplumları öncesinde sanatçı ve tüketici arasında paylaşılan sosyolojik bir olgu alanı olarak yönlendirilen, oldukça bütünleşmiş bir ortak zevk alanından söz edilebilir. Oysa sanatçı, farklı estetik talepleri olan bir pazara hitap etmektedir. 
Özgürlüğünü kazanmıştır, ama aynı zamanda belirsiz ve muamma bir ortamda yalnızlaşmıştır da. Dolayısıyla endüstrileşmeyle izm'ler yerini bireysel çabalara bırakmıştır. $\mathrm{Bu}$ durum sanatı disipline eden kuralların terk edilmesi sonucunu doğurmuştur. Bireyselciliğin ön plana çıktığı çağdaş sanat sürecinde estetik algıda farklılaşmalar meydana gelmiştir. Bu farklılıkların ortaya çıkmasını sağlayan üretici ve tüketici konumundaki sanatçı ve izleyicinin arz-talep ilişkisi olmuştur.

Dolayısıyla suje (özne) olan insanoğlu, sanayi toplumunda mekanik ve karmaşık bir üretim sürecinin basit ve sıradan işleri yapan bir hale gelmiştir. "Kitle toplumunda insanın nasıl çalışacağı, nasıl eğleneceği, nasıl tüketeceği...gibi giderek daha da yoğunlaşan bir eksende belirlenmeye ve belirmeye başlamıştır. Bu oluşum içinde sanatsal yaratıcılığın en önde gelen öğesi, kaçınılmaz olarak özgünlük ve özgürlük olarak nitelenmektedir" (Şaylan, 2009: 103). Sanayileşmeyle kapitalist sistemin kar güdüsü aşırı üretimle beraber aşırı tüketimi de karşımıza çıkarmıştır. Adeta insanların robotlaştıılarak seri üretim aracı haline getirildiği bu dönem, insanı mekanik, tekdüze ve robotik bir yaşam biçimine itmiş, tüketim nesnesine dönüşmesi ise çıkar ilişkilerinin, bencilliğin yaşama egemen olmasına yol açmıştır. Bu gibi ifadeler doğrultusunda özellikle günümüz sanatının tüketim-üretim ekseninde değerlendirilmesine değinen Eker, sanatsal üretimin kaymış olduğu aşırı bireysel tavır ve üretimleri, toplumsal bağlamda uzlaşımsal beğeni ile sonuçlandırma arzusu ve rekabet kavramını da gündeme getirmiştir.

Sanatta rekabet kavramına bağlı yönsemeler, ancak niyeti ve sistemi sürekli tartışılabilecek çeşitli birey eksenli sanat yarışmaları ile güncellenmektedir (Eker, 2005: 318), diyerek sanatta bireysel çabaların ön plana çıktığına vurgu yapılıp, arztalep ilişkisi sanatın biçimlendirilmesinde, üreticiyi/sanatçıyı da etkisi altına aldığı ifade edilmiştir. Dolayısıyla bu rekabet ortamında, sanatçının duygu ve düşüncelerinden ziyade izleyicilerin istek ve arzuları ekseninde sanatsal üretimler ortaya çıkmaktadır. Tüketim Kültürü hayatın tüm alanlarını istila ederek hayatın vazgeçilmez bir parçası olduğu izlenimi vermektedir.

Sanat da bu süreçte kapital(ist) sistemin tüketim nesnelerinin toplumun bireylerine sunulması noktasında adeta bir misyon görevi üstlenmiştir. Bu durum sanatın toplumsal sorumluluklarını ortadan kaldırarak sanata alışkın olmadığı yeni bir alan oluşturmaktadır denilebilir. Tüketim kültürü, hayatın tüm alanlarını istila ederek hayatın vazgeçilmez bir parçası olmuştur. Sanat da bu süreçte maalesef kapitalist sistemin tüketim nesnelerinin toplumun bireylerine sunulması noktasında adeta bir misyon görevi üstlenmiştir. 
Atık nesnelerin henüz ön plana çıkmadığı modern öncesi zamanlarda her nesne bir başka nesnenin formuna dönüşebileceği için hiçbir şey kolay kolay atıklaştırılmazdı. Ama modern-çağdaş olduktan sonra üretilen her nesne üretildiği andan itibaren hızla atığa dönüşmektedir; hatta insan bile. Aşırı modern olmak kadar tehlikeli bir şey yoktur, bir de bakarsınız modası geçiverir insanın. Çünkü modası geçmek atığa dönüşmektir. İnsan sadece modern zamanın atığına değil, kentsel dönüşümle birlikte mekânın da atığına dönüşmektedir. İnsanlar daha çok müstakil yapılarda ve kırsal alanlarda yaşamayı tercih etmektedir. Modern bireylerin hep daha yükseğe göz diktiklerinden fazlasıyla insani olan böyle bir talebi olmamaktadır. Her şeyi tasarlanmış politik-siyasi-sosyolojik tasarılara bağlı yaşamlarımızda atığa dönüştürürken, modayı yakalamak için de durmadan yeni yaşamların peşinden koşmaktayiz.

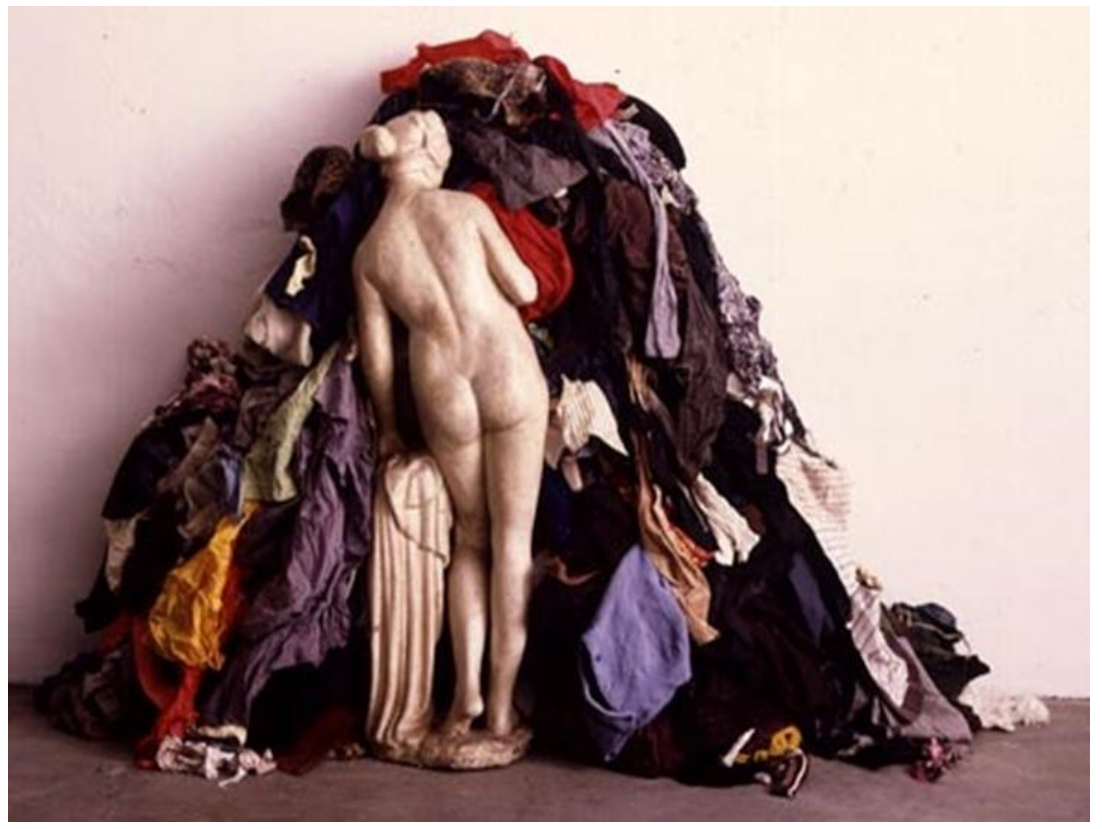

Resim 1. Michelangelo Pistoletto, "Paçavraların Venüsü”, 1967. 
Bu düşünceler bağlamında M. Pistoletto'nun 1967 yılında kompoze ettiği "Paçavralar içinde Venüs" adlı çalışması değerli ile değersizi ve tarihsel ile günceli bir araya getirerek ironik yaklaşımlar sergileyen Art Povera sanatının tipik bir örneği olarak karşımıza çıkmaktadır. Tarihsel süreçlerini düşündüren "Paçavralar içinde Venüs " bir bakıma İtalya'nın zengin sanatsal mirası altında ezilen çağdaş sanatçının çıkmazını akla getirir. Tarihsel yapıtların konum-itibar kazanması süreçlerini irdeleyen Pistoletto, resmin beşiği olan bir ülkede çağdaş sanatla bir jest oluşturur. Bir zamanlar hayranlık uyandıran Venüs, yüzü duvara dönük paçavralar içerisindedir. $\mathrm{O}$ artık geçmiş bir estetik, bir kalıntı olarak karşımıza çıkar. Venüs (resim 1), izleyiciye sırtı dönük bir şekilde konumlanmış olup, bir yığın giysinin önünde durmaktadır.

Michelangelo Pistoletto bu doğrultuda giysileri ve paçavraları dağıtarak klasik motifleri ve akademizmi de sorgulamaktadır. Heykelin salt alçı, bronz ya da mermerden üretilen sanat objesi olması anlayışına karşın, birtakım savrulmuş giysileri dahi heykel olarak sunabilmektedir. Zamansal süreçle birlikte hem gecmişi anımsatma çabası hem de geleceğe doğru bir yol alma durumu vardır.

Yani, akademik heykel anlayışı ve temsil ettiği katı kurallar Michelangelo Pistoletto tarafından parçalanmıştır. Venüs gibi işlevi belli bir sanat eseri hazır yapım ile karşılaştırılabilir hale gelmiştir. Bu tür arayışlar antiform, post minimalizm veya kavramsallık gibi çağdaş sanat anlayışlarını da yansıtmaktadır. Antiform ile birlikte her türlü kullanım nesnesi heykelin bir parcası ya da kendisi olabilmektedir. Örneğin, yoksul bireylerin ya da modern öncesi yaşamların nesneleri ya da insanları atığa çıkarmak gibi bir lüksü hiçbir zaman olmamıştır. Biriktirilen nesneler farklı işlevlere dönüştürülürken, Duchamp'tan çok daha önceleri bir pisuvarın başka bir niyetle kullanılabileceği keşfedilmişti. Duchamp bize her türden nesneye öncelikle işlevsel bir nesne gibi, sonra taze yapılmış bir sanat nesnesi gibi bakmayı öğretmişti. Ancak, bu sadece zengin beyazların dünyasında doğrudur. Afrika'da bir silindir şapka pekâlâ bir taç gibi kullanılabilir, gecekondu semtlerinde eski bir araba bir ev işlevi görebilir.

Atık nesnelerin henüz icat edilmediği eski çağlardan-dönemlerden gelen insanlar, nesneleri atmayıp biriktiriyorlardı ya da başka bir nesnenin formunaişlevselliğine dönüştürüyorlardı. Tüketim toplumlarında nesneler satın alınır-alınmaz hemen atı̆ga dönüşmektedir. Kapital(ist) bir toplumda atığa çıkartılan nesneleri yeniden dolaşıma sokmak ve bir sanat nesnesinin malzemesi yapmak, mevcut sisteme bir muhalefet ve avangard (öncü, yenilikçi) bir tutum olarak durabilir. Bu doğrultuda 20. yüzyılın ikinci yarısında yeni-avangard sanatsal eğilimleri benimseyen yoksul sanat, sanatın ticarileşmesine ve tüketim toplumlarına bir tepki olarak karşımıza çıkıp, kompozisyonlarında-tasarılarında bir anti-form düşüncesiyle hareket ettiğini görmekteyiz. 
Tiyatro yazarı Grotowski'nin dekor, kostüm, aksesuar...gibi sahne öğelerinden kurtularak, oyuncuyu kendi bedeniyle baş başa bırakan "yoksul tiyatro" kavramını ödünç alan kuratör ve yazar Celant'ın isim öncülüğü yaptığı bu yeni-avangard akımın ortak özelliği; gündelik yaşamdaki sıradan-atık nesnelerin-malzemelerin sanat mekanlarına taşınmasıydı.

Celant; "Hayvanlar, sebzeler, mineraller sanat dünyasındaki yerlerini alıyorlar" diye bahsetmiştir. Sanatçıyı ve günlük kullanım malzemesini dönüştüren ve bir simyacıya benzeten Celant, bir bakıma yoksul sanat izleyicisini malzemelerin geçirdiği fiziksel, kimyasal ve biyolojik süreçleri de izlemeye teşvik etmektedir. Yoksul Sanat (Arte Povera) terimi zaman içinde sadece İtalyan sanatçıları bünyesinde toplansa da, aslında yaşamını İtalya'da geçiren Yunan sanatçı Kounellis, bu eğilimin başından beri içerisinde yer almaktadır.

1960'lardan beri çalışmalarına ateş, toprak, altın, taş...gibi element ve nesneleri koyan sanatçı, Arte Poveranın simyaya yönelik ilgilerinin bir göstergesi olmuştur. Bir keresinde galeri ortamına on bir tane canlı at yerleștirerek, galeriyi bir ahıra; sanat yapıtını da nefes alıp-veren bir varlığa dönüştürdüğünü biliyoruz. Sanatçının 2013'te Türkiye-İstanbul'daki bir çalışmasında (resim 2), galeri mekânını bir köşegen gibi çaprazlama ikiye bölen büyük bir yerleştirmeyi kompoze etmiştir. Demir raylar üzerine yerleştirdiği aralıklı vagonlardan oluşan yapıtın vurucu kısmı vagonların taşıdığı malzemelerden kaynaklanmıştır. Vagonların birinin içinde yün, bir diğerinin içinde İznik ve Kütahya'ya ait seramik parçaları, bir diğerinde tuğla taşları, bir diğerinde çuval bezi, ötekinde kömür bir diğer vagonda ise çocukluğumuza ait bir malzeme olan eski dikiş makineleri yer almıştır. Bu enstalasyon (yerleştirme) hem parçaları hem de bütünüyle, endüstri toplumunun doğuşu ve ilerleyişi aynı zamanda ise kültürel değer kavramlarını irdeleyen bir yapıt olarak karşımızda durmaktadır. 


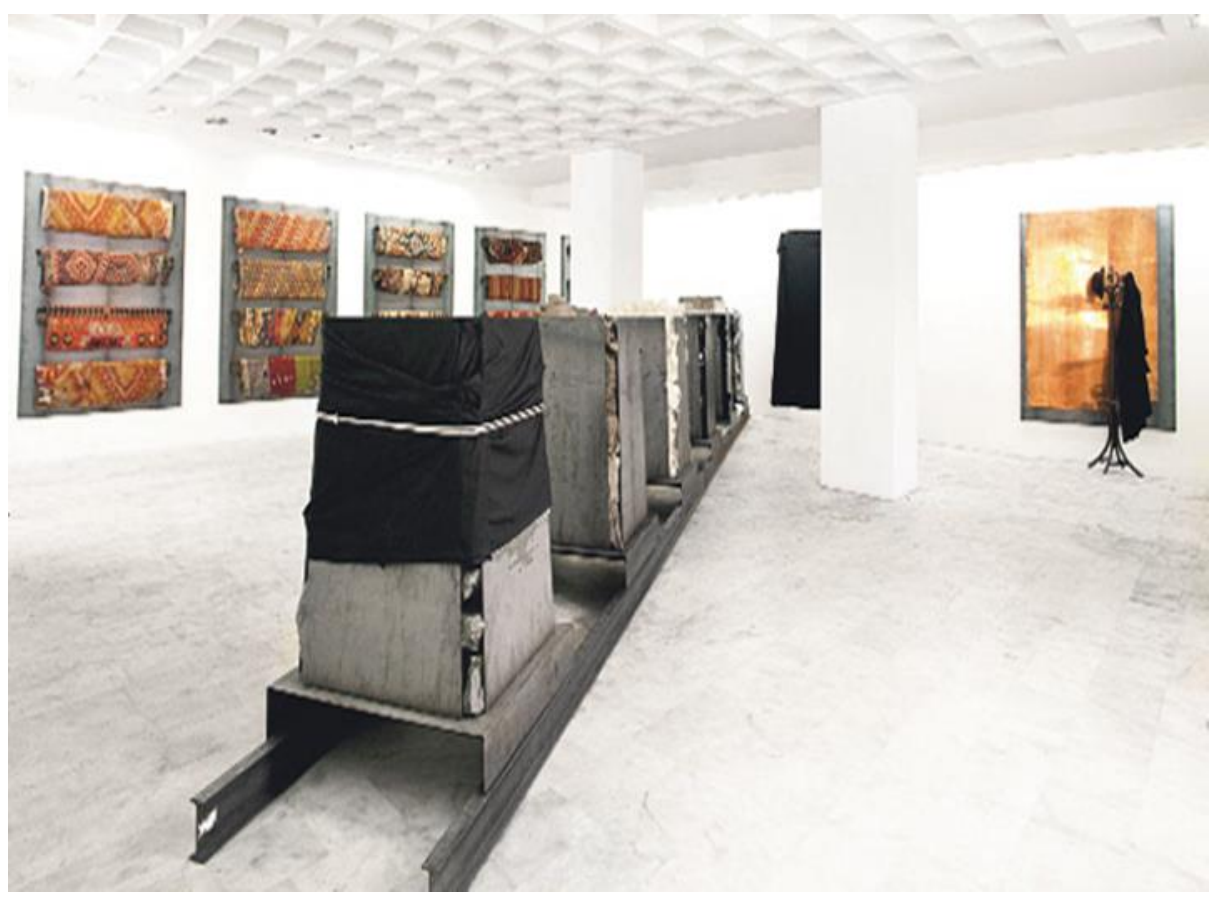

Resim 2. Jannis Kounellis, “Yoksul Sanat”, Galeri Artist, İstanbul, 2013.

Kounellis, sanat çalışmalarında bu eğilimi devam ettiren ve kullandığı malzemelerle etkili sanat yapıtlarına imza atmış bir sanatçıdır. İstanbul Galeri Artist’te sergilenen sanat yapıtlarında Anadolu'ya özgü malzemeleri yapıtlarına ekleyen sanatçı, adeta kültürler arası bir diyaloğun metnini yazmış gibi görünüyor.

$\mathrm{Bu}$ metnin içinde yer alan yerleştirmelerden ilki eski kilim ve halılardan tasarlamış olduğu çalışmadır. Yerleştirmenin her bir parçası, dörder kilim ve halının kendi içinde desen üslubuna göre yerleştirmesinden oluşmaktadır (resim 2). Sanatçı her bir parça ile kendi içinde birbiri ile oldukça uyumlu bir kültür mozaiği inşa etmiş gibidir. Anadolu'dan çıkmış duyarlılıkları, kültürel birikimleri, inançları ve yaşama dair sayısız ara renkleri yansıtan ve barındıran eserleri kendi özgür anlayışlarıyla yorumlayan sanatçı, çalışmalarını adeta yeni ifadelerle donatmıştır. 
Kompoze edilen sanat çalışmaları ve çalışmalarda kullanılan nesnelerin tamamen değersiz nesnelerden oluşturulmasından adını alan "Yoksul Sanat", sanat tarihinde en önemli eğilim-anlayışlardan biri olmuştur. Ayrıca, Yunan sanatçı Kounellis'in kompoze ettiği çalışmalar, The Tate Modern Museum ve MOMA gibi dünyaca ünlü müzeler de dâhil dünyanın birçok noktasında da sergilenmiştir. Demir kasalardan oluşturulan vagon ve ana malzemesi demir olan kafes formu kullanılmış olan çalışmasında ayrıca İznik Seramik parçalarına da yer verdiğini (resim 2) görmekteyiz. Sonuç bağlamında Arte Povera'nın geçmişine baktığımızda, öncelikle ortaya çıkışındaki sosyo-kültürel ve ekonomik unsurların ideolojik kurgulamalarla ne denli zorlayıcı faktörler yaratmış olduğunu ve temelde "insan" olgusunun bu unsurlar altında giderek daha da güçsüz hale geldiğini ifade etmek gerekir. Tüm bu referanslarla birlikte, sanatın öz'e yani saf olana geri dönüşü, sanatçıların farkındalık kazandırma ve eleştirel bir tavır takınma süreçleri Arte Povera'nın ruhunu oluşturmaktadır. Daha somut örneklerden ilerlersek, Arte Povera'nın ortaya çıktığ yıllar olan 60'lar ve İtalya'nın Torino şehri, dönemin sosyal çalkantılarının nüks ettiği yer ve zamana tekabül etmesi anlamında oldukça önemli bir yer tutar. İtalya'nın endüstrileşmesinde merkez olan şehrinde işçi ve halkın "ilerleme" ve "üretim” için sağlıksız koşullarda, özlük haklarından yoksun bir şekilde sanayi patronlarına hizmet etmeleri bir noktadan sonra patlamalarla sonuçlanmıştır. Kapitalizmin 'insan'1 umursamayan evrimi içinde bu tarihlerde etki eden olaylar, sanatçıların da tepkisini çekmiştir. Onlar insandan alınan değerin kendisine iade edilmesini, insan sanat ilişkisinden yola çıkarak da sanatın değerini tekrardan tartışmaya açmışlardır. İnsan'ın özüne yönelmek ya da sanatın özüne geri dönmek, insan olgusunu onun içinde kendini var ettiği kültür ve ona yaşam alanını sunan doğa olgusunu bir araya getirerek, yerinden oynatılmış taşları tekrardan yerine oturtan Yoksul Sanat'ın sanatçıları bu ideolojik kurgulamalarını 1967'de Germano Celant'ın yayınlamış olduğu bildiri ile tescillemiş oldular. İnsanı ve sanatı, Amerika'nın yapılandırdığı endüstri ve pompaladığı tüketim kültürüne karşı öncelikle malzemenin niteliğinden başlayarak endüstrinin karmaşıklığından uzaklaştırmak, sonrasında ise basit olana yani özüne geri döndürmek burada temel olan belirleyiciler olmuştur.

$\mathrm{Bu}$ gibi düşünceler doğrultusunda ulaştığımız varg1/lar: Toplum mühendisleri tarafından tasarlanan politik ve projeye dayalı hayatların içlerine yerleştirilen birey ve bireyler, atık olarak üretim safhasının dışına çıkartılan çeşitli nesneleri yoksul sanat düşüncesi bağlamında keşfettikçe yeniden algılamayı, anlamayı, sezmeyi, bakıpgörmeyi ve kendini biçimlendirmeyi öğreneceklerini ön görebiliriz. 


\section{Sonuç}

21. yüzyıla doğru gelindiğinde sanatta elle tutulamayacak değişimler ve gelişmeler ortaya çıkmıştır. Günümüzde "sanat" denilen kavramın etrafında sonu gelmez tartışmalar devam etmektedir. Modern, modernizm, modernist, postmodern, postmodernizm, postmodernist, çağdaş, güncel, kavramsal sanat, kültür, tüketim kültürü ve görsel kültür gibi kavramlar kargaşası günümüz sanatını anlaşılmaz kılmanın yanında sanatçıyı çeşitli uçuk fikirleri ve ürünleri de sergilemeye teşvik etmektedir. Yeryüzündeki siyasal, sosyolojik, kültürel ve ekonomik düzenden kültürel taleplere, iletişimsel akıştan sanata dek hemen her şey köklü bir hareket ve değişim içerisindedir. Güzel sanatlar, reklam, popüler film ve video, halk sanatları, televizyon ve diğer performanslar, çevresel yapılar, bilgisayar grafikleri, görsel üretim ve iletişim teknolojilerinin formları gibi modernist anlayışın sonucunda vuku bulmuş bu kavramlar, sanatın çok yönlülügüune katkı sağlamanın yanında özgünlük ve estetik boyutunu da tartışılır duruma getirmiştir. Bu değişim ve süreç neredeyse bir asırdır hissedilen kapitalist yapılanmanın ve düşüncenin ürünüdür diyebiliriz. Çünkü sanatı ve piyasasını elinde tutan, yönlendiren ve "eder"ini tespit ettiğini varsayan elit bir kesim ile karşı karşıyayız. Olabildiğince sanat alıcısını da kendisi oluşturan ve belirleyen bu kesim, günümüz sanatını büyük ölçüde ticaret mantığılyla rahatlıkla yönlendirebilmektedir. Kavramsal sanat düşüncesiyle Marcel Duchamp'in ortaya koyduğu "uriner/pisuar" adlı eseri, body art/vücut (beden) sanatı adı altında kimi sanatçıların insan bedenini farklı kurgularda sergileyebilmesi, happening ve video sanatıyla bazılarının ilginç temaları ortaya koyabilmesi, yoksul sanat adı altında kimilerinin de canlı hayvanları/bitkileri sergileyebilmesi, multi medya teknolojilerinin, sanal teknolojilerinin ve reklam endüstrisinin de ortaya koyduğu her şeye sanat(sal) diyebilmesi gibi "ne yapsan sanat olur" mantığıyla hareket edilmesi ve "kitsch" olan her türden nesnenin de artık sanat sayılabileceği düşüncesini doğurmaktadır.

$\mathrm{Bu}$ düşünceler bağlamında yoksul sanatın sanatçıları/düşünürleri diğer sanat anlayış ve eğilimlerinden farklı olarak yapıtın ve yapıtların düşünce yanıyla yani nesnenin fiziksel özellikleri ve değişkenliği ile ilgilenmişlerdir. Sanat düşüncelerinde hem kültürel-ideolojik malzeme ve hem de atıkların kullanıldığı ve tasarlandığı görülmektedir. Bu düşünceler ekseninde sanat ve sanat eğitiminde önemli bir etki/tesir edeceği düşünülebilir. Kültürel dönüşümler ve dinamiklerin mevcudiyeti kadar hayatiyetinin de büyük oranda görselleştirildiği bir postmodern çağda yaşamaktayız. Kültürü kendi ideolojisi ve tasavvurlarını meşrulaştırma alanı olarak gören bir postmodern dünya aynı zamanda, meşrulaştırmanın da motivasyonlarını önemseyen tacir kimliği ile sanatı taşeron kılma gayretinde olduğunu görmekteyiz. 
Kültürel ekonomiler kendi yarattığı kültürel yeni potansiyellerden beslenmekte, kültürel metinleri ya da sanat eserlerini “değer"i ile "eder”i arasında sıkıştırmakta ve yeni stil yaratımlarını kutsamaktadır. Diğer bir deyişle kültür "fetih" ile "işgal" arasındaki ayrımın küresel anlam kargaşasını insanileştirmek için yeni bir sosyoloji alanı yaratmaktadır diyebiliriz. Bu doğrultuda sanat çalışmaları/işlerinin nasıl görünmesi gerektiğine dair üzerinde uzlaşılmış herhangi bir yol/rota yoksa olguların görünümüyle bağlantılı olan bir olgu da sanatın esasının bir parçası olamayacağıdır. Dolayısıyla estetik de daha baştan tanım dışı kalacaktır. Bu düşünceden de güzelliğin bir öneminin kalmadığı gibi bir sonuç da çıkmamalıdır. Bu sadece sanatla olan arasındaki geleneksel bağını kaybetmiştir. Güzellik, insan yaşamında her daim önemli olmuştur ve bundan ötürü de sanatkârlar her daim ona ulaşmaya çalışmışlardır. Lakin sanatçılar aynı zamanda, eğer ulaşmaya çalıştıkları sanat gerekli kılıyorsa, tiksintinin ve iğrenç olanın da ardına düşmelidir. Dolayısıyla, sanatın sonu dediğimiz de aslında yeni bir kültürel ve sanatsal gerçekliğin ve çoksesliliğin başladığının bir işaretidir. Günümüzde sanatı ve sanat eğitimini gittikçe çöken bir sosyo-kültürel ortamda alıcısına ulaştırmak kültür örüntüsüne bir katkı sağlamamaktadır. Bu noktada sadece aktarıcı bir işlev görür ki bu da kişiliksiz bireylerin kişiliksiz bir kültür ortamında kişiliksiz bir sanat eğitimi almalarına neden olabilmektedir. Bugün sanatçı olmak, görsel yöntemlerle felsefe yapmakla eşdeğerdir. Hiçbir sınır ve kısıtlama kalmamıştır. Gerekirse her şey araç-amaç olarak da kullanılabilir. Bundan ötürü sanatın sonu düşüncesi, sanatçıların düşüncelerini-imgelerini diledikleri şekilde ve ifade edebildikleri, ama bu konuda sanat eğitimine de çok ciddi şekilde yaklaşılması gerekmektedir.

Atık nesneler, doğada kendiliğinden bulunan malzemeler, gazeteler, et parçaları, eski kıyafetler, şipşak resimler, araç lastikleri, eski oyuncaklar, şişelenmiş ölü gaz, fil dışkısı, insan dışkısı, canlı atlar, taşlar, çöpler-atıklar, tarlalar, bitkiler, harabeler vb. modernizm ve postmodernizmin son evresini tanımlayan yoksulluk, bugünün sanatsal pratikleri veya eleştirel hassasiyetleri arasında bir bakıma hiçbir bağlantı kalmadığını göstermektedir. Günümüzün sanatçısı artık bir ürün ortaya koymaktan öte, tasarlayabilen ve belki de bu tasarlama sürecine yaratıcı bir düşünür olarak eklemlenmesi gereken bir özneye dönüşmüştür. Kültürün uluslararası ölçütü olarak kabul edilen büyük organizasyonlarda, bugün için revaçta olan ürünler aracılığıyla kültürün hangi mecraya sürüklendiği ve kapital yapılanmanın gereği olarak, Batının hangi argümanlarla-tenkitlerle hareket ettiği de kolaylıkla gözlenebilmektedir. Postmodernizm çatısı altında toplanan bu süreç, endüstri sonrası dönemde yeni bir toplumsallık ve kültürel etkilenim koşullarıyla uğraşırken, kentsel ölçekte olup-bitenlerden ve sanat dışındaki alanların da işin içine karıştığı çok yönlü bir kültürel atmosferi yaratmış durumdadır. 
Dolayısıyla artık sanat eğitimindeki zorlamaların ve eleştirinin emre hazır prototip (gösterim, sunum)'lerinin sürekli değişme ihtimalinin dikkate daha fazla alınacağını söylemek mümkündür. Sanat eğitiminin görsel kültür eğitimi olarak karakterize olduğu günümüzde, kültür ve tüketim eksenli içeriklerin müfredatlaşabileceği, bulunulan coğrafyalarda bireylerin bakış açısına göre kültürel motif ve malzemelerin ekolojik sahalarda-alanlarda daha çok sorgulanacağı, kolay bulunan ve tüketilen her türlü yapay ve doğal nesnelerin de sanat ürününe dönüşebileceğini, çoklu okur-yazarlıkların mutlak olarak sanat eğitiminin yöntem yapılanmalarını karakterize edeceğini ön görebiliriz. Bu hususta sanatta çok önemli ürünler ve tasarımlar ortaya koymak için varlıkların, durumların, fenomenlerin değişik ve çok kapsamlı duyumsanması, algılanması, bir gerçekliğin görülebilen boyutlarının ötesinde içsel bağlamlarının sezilebilmesi ve imgelenebilmesi gerekmektedir.

Sonuç olarak gelecekte sanat ve sanat eğitimine geçmiştekinden ve şimdikinden daha farklı unsurların dâhil olabileceğini ve özellikle birçok alan ve disiplin ile bütünleşen bir yapıya dönüşebileceğini, sanatta ve sanat eğitiminde "yenilik" için temel ölçütün "şimdi" değil, "gelecek" olacağını ön görmemiz mümkün görülmektedir. 


\section{Kaynaklar}

BAUDRILLARD, Jean. (Çev. Hazal Deliceçaylı ve Ferda Keskin), Tüketim Toplumu, Söylenceleri Yapıları, 6. Baskı. İstanbul: Ayrıntı Yayınları, 2013.

DEDE, E. 1960 Sonrası Tüketim Kültürünün Sanata Yansımaları, Kadir Has Üniversitesi: Edebiyat Fakültesi Dergisi, 17-45, 2015.

EKER, M. Sanatsal Üretimin Tüketimsel Dirençlere Yönelik Stratejik Gerekleri, Atatürk Üniversitesi Sosyal Bilimler Enstitüsü Dergisi. (Cilt 6/Sayı 2), Sf. 311-323, 2005.

FEATHERSTONE, Mike. (Çev. Mehmet Küçük), Postmodernizm ve Tüketim Kültürü, (3. Baskı), İstanbul: Ayrıntı Yayınları, 2013.

FEATHERSTONE, Mike. (Çev. Cumhur Atay), Kültürel Üretim, Tüketim ve Kültürel Alanın Gelişmesi, Kültür Kuramı, (1. Baskı), İstanbul: Pales Yayıncılık, 2014.

HALL, Stuart. (Çev. S. Hakan Tuncel), Yerel ve Küresel: Küreselleşme ve Etkinlik, Mülkiye Dergisi, Cilt: 38, Sayı: 2, 2014.

ŞAYLAN, Gencay. Postmodernizm, (4. Baskı), Ankara: İmge Kitabevi Yayınları, 2009.

YAŞAR, Mesut. Tüketim Toplumu ve Sanat İlişkisi, Elektronik Sosyal Bilimler Dergisi Www.E-Sosder.Com, Issn:1304-0278, 2006.

YILMAZ, Mehmet. Modernizmden Postmodernizme Sanat, (1. Bask1), Ankara: Ütopya Yayınları, 2006.

YILMAZ, Mehmet. Sanatçıları Okumak ya da Postmodern Söyleşiler, (1. Baskı), Ankara: Ütopya Yayınları, 2009. 